\title{
Forage Yield as Affected by Mixing Rates of Egyptian clover (Trifolium alexandrinum L.) With Ryegrass (Lolium multiflorum ) Grown in Sandy Soil.
}

\author{
Sary, G.A*., El-Naggar, H.M.,*and Bakhoum Gehan, Sh.H.** \\ *Prof. of Agronomy, Fac. of Agric. Benha Univ. \\ **Field Crops Research Dept., National Research Centre, Cairo, Egypt
}

\begin{abstract}
Two field experiments were conducted during the winter seasons of 2008/2009 and 2009/2010 in Research and Production Station of National Research Centre, Al Emam Malek Village, Al Nubaria District, Al Behaira Governorate, Egypt. Experiments aimed to study potential of mixture of Egyptian clover with ryegrass to increase forage yield and its quality grown under sandy soil conditions.

Five treatments were used i.e ryegrass (pure stand) $12 \mathrm{~kg}$ seeds/fed., clover (pure stand) $20 \mathrm{~kg}$ seeds/fed., $1 / 4$ Ryegrass $+3 / 4$ clover, $1 / 2$ Ryegrass $+1 / 2$ clover and $3 / 4$ Ryegrass $+1 / 4$ clover.

Fresh and dry forage yield/fed. were determined for the three cuts as ton /fed. (First cut 60 days after sowing, second 50 days from the first while third cut 40 days later.) during the two seasons. Chemical composition and nutritional evaluation for dry forage yield was conducted. The obtained results showed that treatment of mixing $3 / 4$ clover $+1 / 4$ ryegrass mixture was the best treatment in fresh and dry yields as well as chemical components and nutritive evaluation i.e. crude protein, crude fiber, ether extract, nitrogen free extract, ash, digestible crude protein and total digestible nutrient in both seasons (as combined analysis of two seasons).
\end{abstract}

Key words: Forage mixtures - Egyptian clover -ryegrass.

\section{Introduction}

Egyptian clover is the first forage crop under Egyptian condition; its cultivated area was 1.07 million hectare /year in 2007 (FAOSTAT 2012). Although it gave high forage yield and high protein $\%$ in forage but the dry matter is low.

Ryegrass (Lolium multiflorum, L.) is a native annual winter grass and adopted to a wide range of soils. It erect in habit and thus facilitates harvesting. It give also quick cover after cutting and give a good quality of hay.

Legume-cereal mixtures is low input technology has many useful effects on quantity and quality of forage mixture. It gave high forage yield with high protein content from legume plus high DM \% and carbohydrates\% from cereal which reflect on quantity and quality of forage mixture. Mixtures of Egyptian clover with ryegrass may improve forage yield and its quality. Potential benefits of mixtures include increased yields, protein and forage quality.

Cereals are high important in feeding ruminant animals for their high matter production and low cost. However, cereals forage is poor in protein content which shows their low quality and nutritive value. Regarding to high feed costs of protein supplementation, legumes can be used in livestock nutrition for their high protein content and providing cost saving. Thus grass-legume mixtures generally have high crude protein concentration and low fiber concentration than pure grass stand. (Hamdollah $\boldsymbol{e t}$ al., 2009).

Habernichit and Blake (1999) concluded that crop mixtures clearly have many advantages and are superior to monocultures, providing greater yield and quality stability and better exploiting all the resources available through enhanced crop plasticity. Moreover, annual legume-cereal mixtures have been attributed to weed, disease and insect suppressions. Ross et al., (2003) and (2004) clear that increasing clover stand in mixture of (legume-cereal) clover and triticale or barley or oat increased forage yield and quality. Blaser et al., (2007) concluded that addition of a red clover (Trifolium pretense L.) intercrop to winter cereal grains can supply forage and provide $\mathrm{N}$ to subsequent crops. El- kramany et al., (2009) reported superiority of first cut at 60 DAS in clover forage yield and protein $\%$ followed by mixture of $75 \%$ clover $+25 \%$ triticale but sole barley recorded the best DM\% and carbohydrates\% followed by $25 \%$ clover $+75 \%$ barley.

\section{Materials and methods}

Two field experiments were carried out during winter season of 2008/2009 and 2009/2010. The experimental soil was analyzed according to Chapman \& Pratt 1978. Soil texture was sandy and its characteristics are shown in Table (1)

The experimental design was randomized complete block design experiment with three replicates which were of five seeding rates. Experimental field well prepared through two plugging and leveling then divided into experimental plots $3 \times 3.5 \mathrm{~m}=10.5 \mathrm{~m}^{2}$ (1/400 fed.) fed. $=4200$ $\mathrm{m}^{2}$. Experimental area divided to five equal parts for seeding rates. The first for ryegrass pure stand, the second for clover clover pure stand, the third for 
$75 \%$ of clover and $25 \%$ of ryegrass ,the fourth for $50 \%$ of clover and $50 \%$ of ryegrass, the fifth for
$25 \%$ of clover and $75 \%$ of ryegrass.

Table 1. Mechanical and chemical analyses of the experimental soil.

\begin{tabular}{llllllllll}
\hline Sand\% & Silt \% & Clay\% & $\begin{array}{l}\mathrm{CaCO} 3 \\
\%\end{array}$ & $\begin{array}{l}\text { Organic } \\
\text { matter } \\
\%\end{array}$ & $\begin{array}{l}\text { E.C. } \\
\text { mmhos } \mid \\
\mathrm{cm}^{3}\end{array}$ & $\mathrm{pH}$ & $\begin{array}{l}\text { Soluble } \\
\text { N ppm }\end{array}$ & $\begin{array}{l}\text { Available } \\
\text { P, ppm }\end{array}$ & $\begin{array}{l}\text { Exchan. K, } \\
\text { ppm }\end{array}$ \\
\hline 91.2 & 3.7 & 5.1 & 1.4 & 0.3 & 0.3 & 7.3 & 8.1 & 3.2 & 20 \\
\hline
\end{tabular}

The five experimental treatments can described as follows:

- Ryegrass (pure stand) $12 \mathrm{~kg}$ seeds/fed.

- clover (Pure stand ) 20kg seeds/fed.

- 1/4 Ryegrass $+3 / 4$ clover

$-1 / 2$ Ryegrass $+1 / 2$ clover

$-3 / 4$ Ryegrass $+1 / 4$ clover

All clover seeds were inoculated with specific Rhizobium strain. Clover and ryegrass, and their mixtures were sown on 29 October 2008 and 3November 2009 for the first and second seasons, respectively. The preceding crop was sunflower in the two seasons.

Three cuts were taken from each of the two seasons. First cut was obtained 60days post seeding date, the second cut was obtained after 50 days from the first one, while the third cut was taken after 40 days from the second cut.

Total nitrogen percentage was determined according to Chapman and Pratt (1978). Crude protein content was estimated by multiplying the analyzed total nitrogen by $6.25 \%$ for clover pure; by $\% 6.125$ for clover $75 \%+$ ryegrass $25 \%$ mixture; by 6.00 for clover $50 \%$ + ryegrass $50 \%$ mixture; by $5.875 \%$ for clover $25 \%$ + ryegrass $75 \%$ mixture and by $5.75 \%$ for ryegrass pure.

Crude fiber percentage was determined according to the A.O.A.C (2000)

Chemical analysis of feedstuff samples were analyzed according to A.O.A.C. (2000) method. The investigated nutritive value of obtained forage material of the different treatments from the proposed mixture and their relevant in pure stands included Crude protein(CP), Crude fiber(CF), Ash, Nitrogen free extract NFE),Ether extract(EE), Digestible crude protein(DCP), Total digestible nutrient(TDN) and Total digestible nutrient yield (TDNY) were determined according to the described by NRC(1977).

Data were statistically analyzed according to Snedecor and Cochran (1990). The combined analysis was conducted for the data of two seasons since the results of the two grown seasons followed a similar trend. The least significant differences (LSD) at the level of 5\% significance was used to compare the treatments means.

\section{Results and discussion}

Results presented in Tables 2,3,4, 5 and 6 show effect of seeding rates of either pure stand or mixtures between Egyptian clover (legume) and ryegrass (cereal) at $1^{\text {st }}, 2^{\text {nd }}, 3^{\text {rd }}$ cuts in 2008/2009 and 2009/2010 seasons. Quantity and quality of forage mixture as affected by different seeding rates show significant differences between treatments for all studied characters as combined analysis of two seasons.

\section{Forage Yield}

\section{1- Fresh forage yield (Ton/ Fed.):-}

Table (2) show significant differences between ryegrass, clover mixture in 3 cuts and total of them in fresh forage yield (ton/fed.). The heaviest fresh yield recorded by $2^{\text {nd }}$ cut followed by $1^{\text {st }}$ cut and $3^{\text {rd }}$ cut was the third. The highest fresh forage yield 14.01 ton/fed. produced by $3 / 4$ clover $+1 / 4$ ryegrass in $2^{\text {nd }}$ cut followed by $3 / 4$ clover $+1 / 4$ ryegrass in $1^{\text {st }}$ cut $(13.85$ ton/fed.) and the third was clover pure stand in $2^{\text {nd }}$ cut (13.164 ton/ fed.). Superiority of $3 / 4$ clover $+1 / 4$ ryegrass mixture which recorded the first order in $1^{\text {st }}$ and $2^{\text {nd }}$ cut may be due to integration effect of highest no. of clover plants under the same mixture and the increase in no. of ryegrass and clover from $1^{\text {st }}$ to $2^{\text {nd }}$ to $3^{\text {rd }}$ cuts under trial condition. Results are in harmony with those obtained by Ross et al., (2003\&2004); Awn (2005). Advantage of ryegrass with clover mixtures than their prevalent pure stand in many aspects as fresh yield had been reported by Blaser et al., (2007), El kramany et al., (2009) and Hamdollah et al., (2009). It can be concluded that superiority of pure stand of Egyptian clover under trial condition is logical result it may be due to higher canopy and branches of legumes than cereals (ryegrass). El-Sheikh (1998) found that fahl-ryegrass mixture produced the highest value leafiness on fresh weight basis.

\section{Dry forage yield (Ton/ Fed.):-}

Results presented in Table (3) that treatment of $3 / 4$ clover $+1 / 4$ ryegrass significantly surpassed mixtures of forage crops in dry forage yield in $1^{\text {st }}$ to $2^{\text {nd }}$ to $3^{\text {rd }}$ cuts. In three cuts and total of them. $1.304-2.442$ $3.568 \mathrm{ton} /$ fed. Dry forage yield was arranged in ascending order from $1^{\text {st }}$ to $2^{\text {nd }}$ and $3^{\text {rd }}$ cuts. El Selaimi (1991), Mousa and El- Nabawi (1995), El- 
Sheikh (1998); Riday and Albrecht (2012) stated the same results. In kura clover/red clover mixtures with a grass companion, the optimal seeding ratios between forage legumes were 75:25 kura clover/red clover. Mixtures containing kura clover and red clover had the greatest percentage forage legume dry matter (above 50\%)

Table 2. Fresh forage yield (ton/fed.) of sole and mixture crops as affected by mixing (Combined analysis of 2008/2009 and 2009/2010) .

\begin{tabular}{lcccc}
\hline \multirow{2}{*}{ Treatments } & \multicolumn{4}{c}{ Fresh forage yield (ton/fed.) } \\
\cline { 2 - 4 } & $1^{\text {st }}$ cut & $2^{\text {nd }}$ cut & $3^{\text {rd }}$ cut & Total \\
\hline Ryegrass & 8.516 & 8.800 & 7.772 & 25.088 \\
clover & 11.848 & 13.164 & 10.099 & 35.111 \\
3/4 clover, 1/4 Rye & 13.858 & 14.017 & 10.870 & 38.746 \\
1/2 clover, 1/2 Rye & 12.680 & 13.000 & 9.783 & 35.463 \\
1/4 clover, 3/4 Rye & 10.944 & 11.716 & 8.924 & 31.584 \\
mean & 11.569 & 12.139 & 9.490 & 33.198 \\
L.S.D. at 5\% & 0.310 & 0.300 & 0.340 & 0.830 \\
\hline
\end{tabular}

Table 3. Dry forage yield (ton/fed.) of sole and mixture crops as affected by mixing (combined analysis of 2008/2009 and 2009/2010)

\begin{tabular}{ccccc}
\hline Treatments & \multicolumn{4}{c}{ Dry forage yield (ton/fed.) } \\
\hline Ryegrass & $1^{\text {st }}$ cut & $2^{\text {nd }}$ cut & $3^{\text {rd }}$ cut & Total \\
clover & 0.985 & 1.811 & 2.957 & 5.752 \\
3/4 clover, 1/4 Rye & 0.983 & 2.134 & 3.149 & 6.265 \\
1/2 clover, 1/2 Rye & 1.304 & 2.442 & 3.568 & 7.314 \\
$1 / 4$ clover ,3/4 Rye & 1.207 & 2.309 & 3.405 & 6.921 \\
mean & 1.075 & 2.154 & 3.204 & 6.433 \\
L.S.D. at 5\% & $\mathbf{1 . 1 1 1}$ & $\mathbf{2 . 1 7 0}$ & $\mathbf{3 . 2 5 7}$ & 0.13 \\
\hline
\end{tabular}

\section{Chemical Composition and Nutritional Evaluation:}

The conducted chemical analysis of forage quality components on dry weight basis include the followings:

\section{1-Crude protein (CP):-}

Data presented in Tables $(4,5,6)$ show differences in $\mathrm{CP}$ concentration between mixtures. The results in the same tables $(4,5,6)$ show that clover exerted relatively higher $\%$ of $\mathrm{CP}$ than ryegrass in their pure stand. These results were clear for the second and later cuts of the two seasons .In pure stand of clover CP percentage decreased gradually from $20.79 \%$, to $19.77 \%$, and $16.42 \%$ from $1^{\text {st }}$ cut to $3^{\text {rd }}$ cut respectively Also $\mathrm{CP}$ in ryegrass decreased from $14.96 \%$, to $13.02 \%$, to $11.13 \%$ from $1^{\text {st }}$ cut to $3^{\text {rd }}$ cut .In general, results show that the higher CP content

( $258.34 \mathrm{~kg} / \mathrm{fed}$.) was recorded by mixing $3 / 4$ clover $+1 / 4$ ryegrass in the first cut and $431.62 \mathrm{~kg} / \mathrm{fed}$. in second cut but in the third cut the higher $\mathrm{CP}$ results by clover pure

(517.05kg/fed.) Followed by $3 / 4$ clover $+1 / 4$ ryegrass $(477.06 \mathrm{~kg} / \mathrm{fed}$.$) .$
$\mathrm{CP}$ content increased gradually from the first cut to the third cut. Similar results obtained by Shan chen et al., (2012).

However, CP content of clover clover in mixed was not negatively affected may be due to its high growth rate. These results are in agreement with those obtained by Thompson and Stout (1997).

The above mentioned results indicate that such increase in CP content of the forage plant (either legumes or with mixing with grasses) in the later than the earlier cuts is more likely due to the more leaf/stem ratio of the later cuts than the later ones. Such leaves are more active in CP synthesis and accumulation (Muhrez et al., 1995 and Shan chen et al., 2012).

The obtained results also claimed that for all studied forage mixture of clover and ryegrass the its $\mathrm{CP}$ content were higher with mixing ryegrass with clover than ryegrass pure. These results may be attributed to the benefits of rhizobium inoculation of clover seeds acted positively in fixing ambient nitrogen. Such nitrogen takes its own role in protein synthesis and accumulation for the associated forage plants in their mixture. These results are in harmony with those obtained by Ross et al., (2004). 
The results of this study also indicated that intercropping of clover with ryegrass at the seeding rate of $3 / 4$ clover to $1 / 4$ ryegrass could be used as alternative practice of clover sole crop for high protein production.

\section{2-Crude fiber (CF):-}

Data presented in Tables $(4,5,6)$ show that ryegrass exerted relatively higher $\mathrm{CF}$ than clover in their pure stand or mixing.

These results percentage were clear for the earlier and later cuts of the two seasons. In pure stand of ryegrass $\mathrm{CF}$ percentage increased gradually from $18.90 \%$ to $20.91 \%$ to $22.90 \% \%$ from $1^{\text {st }}$ cut to $3^{\text {rd }}$ cut, respectively. Also clover $\mathrm{CF}$ percentage increased gradually from $16.71 \%$ to $18.72 \%$ to 20.21 $\%$ from $1^{\text {st }}$ cut to $3^{\text {rd }}$ cut. Concerning the mixing effect, the same trend observed $\mathrm{CF} \%$ increased gradually from the first cut to the third cut. The higher CF \% (18.52) results from mixing $1 / 4$ clover + $3 / 4$ ryegrass followed by $1 / 2$ clover $+1 / 2$ ryegrass $(17.90$ $\%$ ) then $3 / 4$ clover $+1 / 4$ ryegrass. Regarding CF content the same Table indicate that in general CF increased gradually from the $1^{\text {st }}$ cut to $3^{\text {rd }}$ cut on all mixing treatments. However, the highest $\mathrm{CF}$ content was reported by $3 / 4$ clover $+1 / 4$ ryegrass $(224.81 \mathrm{~kg} / \mathrm{fed}$.) in the first cut,(483.15kg/fed.) in the second cut, and $(744.82 \mathrm{~kg} / \mathrm{fed}$.) in the later one. Similar results were recorded by El- Selaimi (1991). Such higher content of $3 / 4$ clover $+1 / 4$ ryegrass mixture inspirer of its lower $\mathrm{CF}$ concentration may be attributed to the higher dry matter of such forage mixture.

From the above mentioned results, it is well known that grasses with its nature of steaming structure possess more $\mathrm{CF}$ percentage than leguminous clover in their pure stand. In this respect Fulkerson et al., (2007) reported that grasses has much higher hemicellulose than legumes. Thus, the higher $\mathrm{CF}$ concentration of ryegrass imposed its impact on the lower CF of the associated clover, which came up with nearly moderate CF concentration. In general, those results are in accordance with those obtained by Francisco et $\boldsymbol{a l}$., (2003) and Fulkerson et al., (2007).

\section{3- Ash:-}

Data presented in Tables $(4,5,6)$ reveal that for clover pure in the $1^{\text {st }}$ cut exerted relatively higher ash $\%$ than ryegrass in their pure stand and mixing .These results were clear for the earlier and later cuts. In pure stand of clover ash percentage decreased gradually from $18.18 \%$ to $16.43 \%$ and 14.23 from $1^{\text {st }}$ cut to $3^{\text {rd }}$ cut respectively. Also ryegrass ash\% decreased gradually from $17.05 \%$ to $15.34 \%$ to $13.11 \%$ through $1^{\text {st }}$ cut to $3^{\text {rd }}$ cut. Concerning mixing the same Tables also showed that mixing clover with ryegrass affected ash percentage in all cuts. However, the highest ash \% (17.89) was recorded by mixing $3 / 4$ clover $+1 / 4$ ryegrass followed by $1 / 2$ clover + $1 / 2$ ryegrass $(17.57 \%)$ then $1 / 4$ clover $+3 / 4$ ryegrass.

As regarding the ash content the highest might $(233.24 \mathrm{~kg} / \mathrm{fed}$.) was resulted by $3 / 4$ clover $+1 / 4$ ryegrass followed by $1 / 2$ clover $+1 / 2$ ryegrass (212.01) then $1 / 4$ clover $+3 / 4$ ryegrass (187.16kg/fed.). Ryegrass pure the lowest produce ash content $(167.99 \mathrm{~kg} / \mathrm{fed}$.$) . Ash content increased$ from $1^{\text {st }}$ cut to $3^{\text {rd }}$ cut in all mixing treatments. In general, these results were in accordance with those reported by El- Selaimi (1991) and Abd El- Shafy and Ali (1996). The relatively high ash content of the earlier cuts as compared with the later one in ryegrass and clover may be attributed to mineral absorption and accumulation as a result of the high activity of the plants during the active earlier studies of growth than later ones.

\section{4-Nitrogen free extract (NFE):-}

The effect of mixing clover with ryegrass in NFE percentage and content are shown in Tables $(4,5,6)$ which showed relatively higher with noticeable magnitudes NFE percentage of ryegrass than clover in their pure stand. Moreover, the same Tables $(4,5,6)$ also showed that in general, NFE percentage increased gradually from $1^{\text {st }}$ cut through $3^{\text {rd }}$ one for either grasses or legumes in their pure stands. The same trend was also true for different mixtures of ryegrass and clover. El -Hakim (1990) and El kramany et al., (2009) reported similar results in this respect.

As for NFE content as $\mathrm{kg} / \mathrm{fed}$. Tables $(4,5,6)$ show that NFE content highly increased from $1^{\text {st }}$ cut to $3^{\text {rd }}$ cut, and the highest NFE content was recorded by $3 / 4$ clover $+1 / 4$ ryegrass in the $3^{\text {rd }}$ cut $(1602.9)$. In general, there was a progressive and consistent increase nitrogen free extract as the clover seeds increased in the mixture. This was true in the three cuts. In addition, the promoting effect of clover in enhancing nitrogen free extract is to be expected since clover plant is a leguminous plant and can get benefit from nitrogen gas through nodule bacteria root of clover secrete nitrogen compounds which stimulate the nitrogen uptake of neighbor in ryegrasses. 


\section{5-Ether extract (EE):-}

The effect of mixing clover with ryegrass in ether extract percentage and content are shown in Tables $(4,5,6)$ which show relatively higher with noticeable magnitudes EE percentage for ryegrass than clover. Moreover, in generally EE percentage decreased gradually from $1^{\text {st }}$ cut through $3^{\text {rd }}$ one for grasses and legumes in their pure stands. The same trend was also clear with different mixtures of ryegrass and clover. As for EE content dada in Tables $(4,5,6)$ show that Ether extract content highly increased from $1^{\text {st }}$ cut to $3^{\text {rd }}$ cut and that the highest EE content was recorded by pure stand of ryegrass in the $3^{\text {rd }}$ cut $(74.37 \mathrm{~kg} / \mathrm{fed}$.). The same Table also show that EE content of pure stand of ryegrass the EE content increased significantly by mixing clover with ryegrass in the $2^{\text {nd }}$ and $3^{\text {rd }}$ cuts.

The above mention increase in EE content with different reversely EE percentage is more likely due to the progressive increase of dry weight of the plants from the earlier cuts to the latter one.

\section{6- Digestible crude protein (DCP):-}

Data presented in Tables $(4,5,6)$ show differences in DCP concentration between mixtures. The same Tables showed that clover exerted relatively higher DCP than ryegrass in their pure stand. These results were clear for the second and later cuts of the two seasons. In pure stand of clover DCP percentage decreased gradually from $15.18 \%$, to $14.31 \%$ to $11.46 \%$ from $1^{\text {st }}$ cut to $3^{\text {rd }}$ cut, respectively. Also DCP in ryegrass decreased from $10.19 \%$, to $8.57 \%$, to $6.96 \%$ from $1^{\text {st }}$ cut to $3^{\text {rd }}$ cut .Results also showed that the higher DCP content $(188.09 \mathrm{~kg} / \mathrm{fed}$.) was reported by in mixing $3 / 4$ clover $+1 / 4$ ryegrass in the first cut. but the higher record reported in second cut $306.71 \mathrm{~kg} / \mathrm{fed}$. and in the third cut (363.27) $\mathrm{kg} / \mathrm{fed}$. DCP content increased gradually from the first cut to the third cut. Muhrez et al., (1995) came the same results.

\section{7- Total digestible nutrients TDN:-}

Data presented in Tables $(4,5,6)$ clear differences in TDN concentration between mixtures. The results show that ryegrass pure exerted relatively higher TDN than clover in their pure stand. These results were clear for the second and later cuts of the two seasons .In pure stand of ryegrass TDN percentage decreased gradually from $68.56 \%$, to $66.63 \%$ to $64.85 \%$ from $1^{\text {st }}$ cut to $3^{\text {rd }}$ cut respectively Also TDN in clover decreased from $65.68 \%$, to $64.20 \%$, to $62.43 \%$ from $1^{\text {st }}$ cut to $3^{\text {rd }}$ cut. In general, also showed that the higher Total digestible nutrients yield TDNY(875.33kg/fed.) was obtained for mixing $3 / 4$ clover $+1 / 4$ ryegrass in the first cut, and 1594.24 in the second cut and 2240.97 in the third cut respectively. TDNY content increased gradually from the first cut to the third one. These results are in agreement with those obtained by Muhrez et al., (1995) in this respect it is worthy to note that there was positive correlation between $\mathrm{CP} \%$ and TDN \%.

\section{Conclusion}

It was clear from obtained results that forage yield of pure stand of Egyptian clover produced the highest forage yield (ton/fed.) and protein $\%$ in forage but sole ryegrass gave the highest crude fiber $\%$. Performance of (legume-cereal) mixtures was influenced by cereal density, thus, mixture of $3 / 4$ clover $+1 / 4$ ryegrass may improve forage quality and yield. Potential benefits of mixture include increased yields, increas protein and forage quality, $\mathrm{N}$ contributions from legumes, greater yield stability, and incidence of weeds. Lower total season DM yield at low cereal density was balanced by a greater protein contribution from larger clover components. However, farmers are unlikely to adopt the increased cost and complexity of managing intercrops without demonstrated evidence of potential advantages over mono cropping it is possible to make Egyptian clover-ryegrass mixture by $3 / 4$ clover $+1 / 4$ ryegrass from recommended seeding rates without increasing cost. Generally, it can be concluded that these study need additional studies on effect of forage mixture on animal feeding. 
Table 4. Chemical constituents and total digestible nutrients of the proposed forage mixture and relevant pure stand for percentage and content (kg/fed.) (combined analysis of 2008/2009 and 2009/2010) First cut

\begin{tabular}{|c|c|c|c|c|c|c|c|c|c|c|c|c|c|c|}
\hline & \multicolumn{2}{|c|}{$\mathrm{CP}$} & \multicolumn{2}{|c|}{$\mathrm{CF}$} & \multicolumn{2}{|c|}{ Ash } & \multicolumn{2}{|c|}{ NFE } & \multicolumn{2}{|c|}{$\mathrm{EE}$} & \multicolumn{2}{|c|}{$\mathrm{DCP}$} & \multicolumn{2}{|c|}{ TDN } \\
\hline Treatments & $\%$ & content & $\%$ & content & $\%$ & content & $\%$ & content & $\%$ & content & $\%$ & content & $\%$ & content \\
\hline Ryegrass & 14.96 & 147.33 & 18.90 & 186.17 & 17.05 & 167.99 & 45.69 & 457.73 & 3.40 & 33.49 & 10.19 & 101.78 & 68.59 & 680.60 \\
\hline Clover & 20.79 & 204.41 & 16.71 & 164.25 & 18.18 & 178.75 & 41.74 & 370.98 & 2.58 & 25.31 & 15.18 & 150.15 & 65.68 & 648.42 \\
\hline 1/4 Rye, 3/4 Clover & 19.81 & 258.34 & 17.24 & 224.81 & 17.89 & 233.24 & 42.22 & 522.71 & 2.84 & 37.03 & 14.34 & 188.09 & 66.72 & 875.33 \\
\hline $1 / 2$ Rye, $1 / 2$ Clover & 18.66 & 225.17 & 17.90 & 216.05 & 17.57 & 212.01 & 43.39 & 504.71 & 2.49 & 30.05 & 13.37 & 161.63 & 67.44 & 815.10 \\
\hline $3 / 4$ Rye, $1 / 4$ Clover & 16.14 & 173.55 & 18.52 & 199.04 & 17.41 & 187.16 & 44.88 & 473.32 & 3.06 & 32.84 & 11.06 & 120.61 & 67.96 & 737.80 \\
\hline Mean & 18.07 & 201.76 & $\mathbf{1 7 . 8 5}$ & 198.06 & 17.62 & 195.83 & 43.58 & 465.89 & 2.87 & 31.75 & 12.83 & 144.45 & 67.28 & 751.45 \\
\hline L.S.D.at $5 \%$ & & 6.29 & & 6.98 & & 6.60 & & 21.06 & & 1.26 & & 4.35 & & 26.35 \\
\hline
\end{tabular}

Table 5. Chemical constituents and total digestible nutrients of the proposed forage mixture and relevant pure stand for percentage and content (kg/fed.) (Combined analysis of 2008/2009 and 2009/2010) Second cut.

\begin{tabular}{|c|c|c|c|c|c|c|c|c|c|c|c|c|c|c|}
\hline \multirow[b]{2}{*}{ Treatments } & \multicolumn{2}{|c|}{$\mathbf{C P}$} & \multicolumn{2}{|c|}{$\mathbf{C F}$} & \multicolumn{2}{|c|}{ Ash } & \multicolumn{2}{|c|}{ NFE } & \multicolumn{2}{|c|}{ EE } & \multicolumn{2}{|c|}{ DCP } & \multicolumn{2}{|c|}{ TDN } \\
\hline & $\%$ & content & $\%$ & content & $\%$ & content & $\%$ & content & $\%$ & content & $\%$ & content & $\%$ & content \\
\hline Ryegrass & 13.02 & 235.79 & 20.91 & 378.59 & 15.34 & 277.72 & 47.92 & 875.08 & 2.82 & 51.07 & 8.57 & 155.95 & 66.63 & 1212.05 \\
\hline Clover & 19.77 & 421.93 & 18.72 & 399.38 & 16.43 & 350.51 & 42.69 & 870.78 & 2.40 & 51.22 & 14.31 & 306.71 & 64.20 & 1374.40 \\
\hline 1/4 Rye, 3/4 Clover & 17.68 & 431.62 & 19.79 & 483.15 & 16.13 & 393.89 & 43.92 & 1049.40 & 2.50 & 60.93 & 12.52 & 306.49 & 65.10 & 1594.24 \\
\hline $1 / 2$ Rye, $1 / 2$ Clover & 15.10 & 348.59 & 20.12 & 464.57 & 15.93 & 367.82 & 46.28 & 1015.73 & 2.58 & 59.46 & 10.35 & 240.57 & 65.61 & 1519.04 \\
\hline 3/4 Rye, $1 / 4$ Clover & 13.86 & 298.57 & 20.54 & 442.32 & 15.67 & 337.53 & 47.28 & 976.62 & 2.65 & 57.08 & 9.28 & 201.00 & 66.10 & 1428.06 \\
\hline Mean & 15.89 & 347.30 & 20.01 & 433.60 & 15.90 & 345.50 & 45.62 & 957.52 & 2.59 & 55.95 & 11.01 & 242.14 & 65.53 & 1425.56 \\
\hline L.S.D.at 5\% & & 8.55 & & 10.88 & & 8.59 & & 29.38 & & 1.53 & & 5.93 & & 36.39 \\
\hline
\end{tabular}

Table 6. Chemical constituents and total digestible nutrients of the proposed forage mixture and relevant pure stand for percentage and content (kg/fed.) (combined analysis of 2008/2009 and 2009/2010) Third cut

\begin{tabular}{|c|c|c|c|c|c|c|c|c|c|c|c|c|c|c|}
\hline & \multicolumn{2}{|c|}{$\mathbf{C P}$} & \multicolumn{2}{|c|}{$\mathbf{C F}$} & \multicolumn{2}{|c|}{ Ash } & \multicolumn{2}{|c|}{ NFE } & \multicolumn{2}{|c|}{ EE } & \multicolumn{2}{|c|}{ DCP } & \multicolumn{2}{|c|}{ TDN } \\
\hline Treatments & $\%$ & content & $\%$ & content & $\%$ & content & $\%$ & content & $\%$ & content & $\%$ & content & $\%$ & content \\
\hline Ryegrass & 11.13 & 329.24 & 22.90 & 677.01 & 13.11 & 387.51 & 50.35 & 1518.57 & 2.52 & 74.37 & 6.96 & 213.61 & 64.85 & 1977.71 \\
\hline Clover & 16.42 & 517.05 & 20.21 & 636.41 & 14.23 & 447.95 & 47.38 & 1322.58 & 1.77 & 55.74 & 11.46 & 363.27 & 62.43 & 1972.02 \\
\hline 1/4 Rye, 3/4 Clover & 13.37 & 477.06 & 20.88 & 744.82 & 13.95 & 497.74 & 49.94 & 1602.92 & 1.87 & 66.54 & 8.87 & 318.01 & 62.71 & 2240.97 \\
\hline 1/2 Rye, $1 / 2$ Clover & 12.82 & 436.46 & 21.32 & 725.78 & 13.57 & 462.06 & 50.35 & 1569.19 & 1.95 & 66.23 & 8.39 & 287.42 & 63.62 & 2170.35 \\
\hline 3/4 Rye, $1 / 4$ Clover & 11.99 & 384.10 & 22.04 & 706.00 & 12.25 & 392.37 & 51.66 & 1538.72 & 2.07 & 66.32 & 7.70 & 247.66 & 64.07 & 2056.39 \\
\hline Mean & 13.15 & 428.78 & 21.47 & 698.00 & 13.42 & 437.52 & 49.94 & 1510.40 & 2.03 & 65.84 & 8.68 & 285.99 & 63.53 & 2083.49 \\
\hline L.S.D.at 5\% & & 13.03 & & 22.22 & & 13.85 & & 25.29 & & 2.12 & & 8.63 & & 64.33 \\
\hline
\end{tabular}




\section{References}

Abd El-Shafy, A. S. and A. M. Ali (1996). Forage yield and quality of berseem fahl and ryegrass mixture at different seeding rates. Ann. Agric. Sci.Mostohor.34:4, 1405-1414.

A.O.A.C. (2000). Official Methods of Analysis, $17^{\text {th }}$ ed. Association of Official Analytical Chemists, Washington, DC, USA.

Awn, O., S. E. (2005). Effect of mixing some varieties of Egyptian clover and promising strains of ryegrass on the forage yield and quality.

P.h.D. Thesis Dep. Of Agronomy, Fac. of Agric. Moshtohor (Banha Branch) Zagazig Univ.

Blaser, B. C., J.W. Singer and L.R. Gibson (2007). Winter cereal, seeding rate and intercrop seeding rate effect on red clover yield and quality.

Agronomy J., 99(3): 723-729.

Chapman, H. D. and P. F. Pratt (1978). Methods of Analysis for Soils, Plants and Water. Univ. of California, Div. Agric. Sci. Prical Publication 4030, pp:12-19.

El-Hakim, M.S. (1990). Effect of forage mixtures at different mixing ratios on yield and quality. Egyptian Journal of Applied Science 5(7): 804817.

El-karamany, M.F.; Amany, A. Bahr and M.M. Tawfic ( 2009). Forage mixture potential of berseem clover (Trifolium alexandrinum) with triticale ( $X$ triticosecale wittmack) or barley (Hordeum vulgare L.).

Bull. NRC, 34(2): 175-185.

El-Selaimi, H. E. (1991). Productivity of Total Digestible Nutrients Per Feddan of Forage Crops. Ph.D.Thesis, Animal Production. Dept. Fac. of Agric. Alex. Univ.

El-Sheikh, F.T.Z. (1998). Forage yield and quality of fahl clover as affected by mixing with some winter grass.Proc. $8^{\text {th }}$ Con. Agron.Nov.2829 Fac. Agric. Suez canal Univ. Ismailia Egypt.1998.

FAO STAT (2012). WWW. FAO 2012.

Francisco, M.; A. A. Kenneth; M. S. Daniel and B. Paolo (2003). Steer performance on Kura clovergrass and red clover - grass mixed pastures. Agron. J. 95(3): 652-659.

Fulkerson, W. J.; J. S. Neal; C.F. Clarc; A. Horadagoda K.S. Nadraand I. Barchia (2007).
Nutritive value of forage species grown in the warm temperate climate of Australia for dairy cows: Grasses and legumes. Livestock Science107, 253-264.

Habernichit, D.K. and T.K. Blake (1999). Crop mixtures. J. Am. Soc. Brew. Chem., 57: 64-71.

Hamdollah, E.; G. Ahmad and J . Abdollah (2009). Intercropping of cereals and legumes for forage production. Notulae Scientia Biologicae, 1(1): $07-13$

Mousa, M. and E.S. El -Nabawi (1995). Effect of bacterial inoculation on forage yield of berseem-ryegrass mixture. Zagazig J. of Agric. Res. 22,(2):367-376.

Muhrez, A. Z.; A. A.Gaber and M. M. El- Deeb (1995).The evaluation of berseem-Italian ryegrass mixtures under Daqahlia Governorate conditions : 2-Effect of different seeding rates and cutting on some major mineral elements content and feeding values.

J. of Agric. Sci. Mansoura Univ. 20 (3): 1061-1070.

N.R.C. (1977). National Research Council. "Nutrient Requirements of Rabbits". Nat. Acd. Sci.,Washington, D.C.

Riday, H. and K. A. Albrecht (2012). Combining Kura clover with forage legumes and grasses to optimize pasture forage legume content. Agron. J. 104 (2): 353-362.

Ross, S. M.; J. R. King; J. T. O'Donovan and D. Spaner (2004).

Forage potential of intercropping berseem clover with barley, oat, or triticale . Agron. J. 96 (4):1013-1020.

Ross, S. M.; J. R. King; J. T. O'Donovan and R. C. Izaurralde (2003). Seeding rate effects in oat - berseem clover intercrops. J. of Plant Sci. 83(4): 769-778.

Shan Chen, Ji. ; Fen-Ian Tang; Rui-fen Zhu; Chao Gao, Gui-li Di and Yue - xueZhang (2012). Effects of cutting frequency on alfalfa yield and yield components in Songnen plain, Northeast China. African Journal of Biotechnology Vol.11 (21): 4782- 4790.

Snedecor, G. W. and W. G. Cochran (1990). "Statical Methods" $8^{\text {th }}$ ed, Iowa State Univ. Press, Ames, Iowa, U.S.A.

Thompson, D.J. and D.G. Stout (1997). Mixtures of Persian clover with Italian ryegrass or barleyItalian ryegrass for annual forage.

Canadian. J. Plant. Sci. 77:4,579-585. 


\section{"تأثر محصول العلف الناتج من خلط معدلات البرسيم المصري مع الراي جراس النامية فى الأراضى الرملية"}

$$
\begin{aligned}
& \text { أ.د/ جابر عبد اللطيف سارى - أستاذ المحاصيل المتفرغ بكلية الزراعة - جامعة بنها }
\end{aligned}
$$

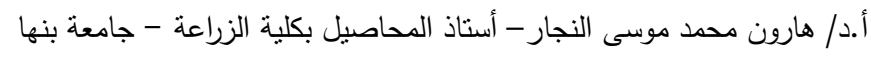

$$
\begin{aligned}
& \text { جيهان شاكر حنا باخوم - باحث مساعد بالمركز القومى للبحوث }
\end{aligned}
$$

أجريث تجربتان حقليتان خلال الموسمين الثنتويين 2008-2009 و 2009-2010 بمحطة تجارب البحوث الزراعية للمركز القومي للبحوث

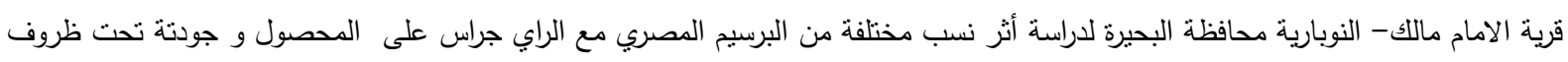
الاراضى الرملية فى تصميم قطاعات كاملة العشوائية فى ثلاث مكررات.

و قد أشتملت التجربة علي 5 معاملات

معاملات المخاليط

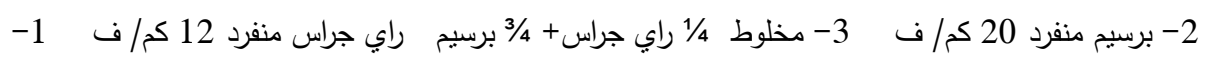

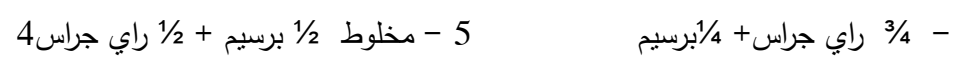

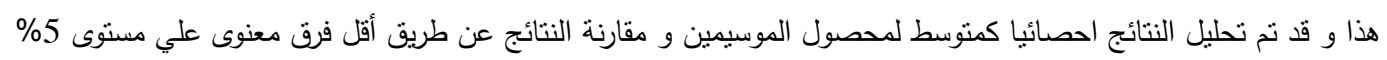

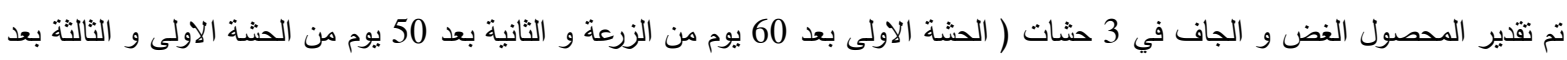
بعد 40 يوم من الثانية خلال الموسيمين الزراعيين. وتقدير النسب المئوية لكل من المركبات المختلفة و كذا محصول الفدان من هذة المركبات على أساس الوزن الجاف .

و أوضحت النتائج 1- تفوق معاملتى البرسيم المنفرد و كذا مخلوط 1/4 راي جراس + 3/4 البرسيم فى محصول العلف الغض و الجاف و النسبة المئوية و محصول كل البروتين الجاف و المهضوم و الدهن المواد الغذائية الكلية

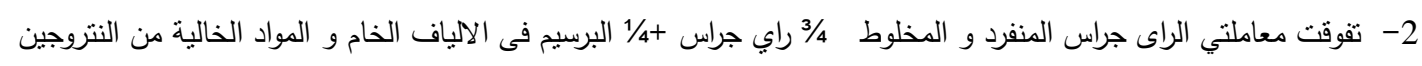

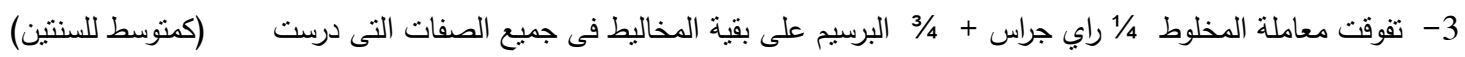

